\title{
Propugnating Effect of Bark of Rhizophora mucronata Against Different Toxicants Viz Carbon Tetrachloride, Ethanol and Paracetamol on HepG 2 Cell Lines
}

\author{
Chitra Jairaman', Syed Ali Mohamed Yacoob ${ }^{1}$,Anuradha Venkatraman², \\ Yogananth Nagarajan', Gnanadesigan Murugesan ${ }^{3}$
}

${ }_{1}^{1} \mathrm{PG}$ and Research Department of Biotechnology, Mohammed Sathak College of Arts \& Science, Shollinganallur, Chennai-119, Tamil nadu, India ${ }^{2} \mathrm{PG}$ and Research Department of Biochemistry, Mohammed Sathak College of Arts \& Science, Shollinganallur, Chennai-119, Tamil nadu, India ${ }^{3}$ Department of Microbial Biotechnology, Bharathair University, Coimbatore-641046, Tamil nadu, India

\section{Key Words}

cytotoxicity, ethanol: water (3:1) extract, toxicants, viable cells

\begin{abstract}
Objective: The aim of the study was to evaluate the hepatoprotective activity of the bark extract (Ethanol: Water) in the ratio of (3:1) of Rhizophora mucronata (BERM) by intoxicating the $\mathrm{HepG}_{2}$ cell lines with different toxicants viz, $\mathrm{CCL}_{4}$, Ethanol and Paracetamol with different concentrations of the extract were used. The $\mathrm{HepG}_{2}$ cell lines were subjected to MTT Assay for studying the cytotoxicity.
\end{abstract}

Methods: $\mathrm{HepG}_{2}$ cells were plated using 96 well plate in $10 \%$ bovine serum, exposed to different toxicants viz, $2 \% \mathrm{CCl}_{4}, 60 \%$ Ethanol and $14 \mathrm{mM}$ Paracetamol respectively. The various test concentrations $(18.85,37.5,75$, 150 and $300 \mu \mathrm{g} / \mathrm{ml}$ ) of bark extract of Rhizophora mucronata was added and incubated for 24 hours. Medium was removed after incubation period and $0.5 \mathrm{mg} / \mathrm{ml}$ MTT(3-(4,5-dimethylthiazol-2-yl)-2,5-diphenyltetrazolium bromide) was added and again incubated for 4 hours at 37oC. Then MTT was removed the crystals was dissolved in DMSO and absorbance was measured at $570 \mathrm{~nm}$.

Received: Sep 21, 2018 Reviewed: Jan 08, 2019 Accepted: Feb 11, 2019

(c) This is an Open-Access article distributed under the terms of the Creative Common Attribution Non-Commercial License (http://creativecommons.org/licenses/by-nc/4.0/) which permits unrestricted noncommercial use, distribution, and reproduction in any medium, provided the original work is properly cited.

(2) This paper meets the requirements of KS X ISO 9706, ISO 9706-1994 and ANSI/NISO Z39.48-1992 (Permanence of Paper).
Results: The result showed that dose dependent increase in percentage of viability at the doses of 18.85 , $37.5,75,150,300 \mu \mathrm{g} / \mathrm{ml}$. The results for the CCl4 intoxicated, at $300 \mu \mathrm{g} / \mathrm{ml}$ of the concentration of the extract, the $\%$ of viable cells was found out to be $99.6 \%$, for Ethanol intoxicated, 97.67\%, and Paracetamol induced, $75.37 \%$, IC50 was $21.53 \mu \mathrm{g} / \mathrm{ml}, 12.61 \mu \mathrm{g} / \mathrm{ml}$ and 21.42 $\mu \mathrm{g} / \mathrm{ml}$ respectively.

Conclusion: Thus, we conclude that, the extract possesses defensive effect against different toxicants and can be used as an alternate drug for hepatotoxicity.

\section{Introduction}

The liver is considered to be the vital and of paramount importance which is involved in the detoxification of viral infections, chronic alcoholism, drugs and xenobiotics [1]. The damaged liver gives a clear indication that the liver has inherited hepatic injury or damaged parenchyma cells which leads to the imbalance in various metabolic functions [2]. There are various agents responsible for the liver damage and hepatic injuries which includes; chemicals, prolonged drug therapy, paracetamol overdose, viruses, alcoholism, different toxicants, viz, $\mathrm{CCl}_{4}$ and Ethanol and environmental pollutants $[3,4]$

Carbon tetrachloride $\left(\mathrm{CCl}_{4}\right)$ is known as toxicant capable of inducing liver damage. It is well known for damaging vital organs of our body viz, kidneys, lungs,
"Corresponding Author

Syed Ali Mohamed Yacoob. PG and Research Department of Biotechnology, Mohamed Sathak College of Arts and Science, Sholinganallur, Chennai, India.

Tel: +91-984-205-2929, +91-741-840-6385

E-mail: syedmicro555@gmail.com

(c) 2019 Korean Pharmacopuncture Institute

http://www.journal.ac 
adrenals, CNS in humans and experimental animals. The possible mechanism of its toxicity has been identified and reviewed to eliminate its toxic capacity and to revive the degenerated cells [5].

Paracetamol overdose may result in hepatic encephalopathy, cardiovascular instability, kidney or renal failure, profound coagulopathy, disturbance in CNS and brain oedema (Prescott, 1996). Its overdose is also attributed to cause side effects viz, vomiting, constipation, insomnia and depression since 1950's [6]. There are other factors may bring into consideration which contribute to an increased risk of hepatic damage in regards to paracetamol administration i.e malnutrition, pre- existing liver disorder, alcohol abuse and reactions with concordant drugs.

In alcoholic fatty liver there are reports stating that there is an increase in lipid accumulation and oxidative stress has been noted [7]. Chronic and excessive ethanol consumption leads to proliferation of cells, fibrosis, cirrhosis and cancer of the liver [8]. Serious damage to hepatocytes occurs as a result of lipid accumulation and oxidative stress due to excess alcohol and chronic exposure. The first stage of alcoholic liver disease (ALD) is fatty liver, followed by oxidative stress then necrosis, fibrosis, cirrhosis and ultimately Hepatic liver failure (HLF).

Thus in this study, the bark extract of Rhizophora mucronata (BERM) have been treated with three major toxicants viz, $\mathrm{CCl}_{4}$, Paracetamol and Ethanol to study their effects and retrieval of regenerative cells on $\mathrm{HepG}_{2}$ cell lines. This study is an attempt to review the different and potent toxicants and their effects on $\mathrm{HepG}_{2}$ cell lines.

\section{Materials Methods}

\subsection{Plant material collection and its extraction}

The bark of $R$. mucronata were collected from Pichavaram Mangrove forest, (latitude: $11^{\circ} 23^{\prime}$ to $11^{\circ} 30^{\prime} \mathrm{N}$ and longitude: $79^{\circ} 45^{\prime}$ to $79^{\circ} 50^{\prime} \mathrm{E}$ ) is located between Coleroon and Vellar estuary in the state of Tamil Nadu, identified in the herbarium of C.A.S. in Marine Biology, Annamalai University, Parangipettai, India and authenticated by Prof Jayaraman, Botanist and Director, PARC, West Tambaram, Chennai, Tamil Nadu, India. A voucher specimen was submitted in the department for future reference. The fresh barks were collected from the healthy stem of the plants. These barks were then packed in Poly ethylene plastic and eventually brought to laboratory. The collected bark samples were separated from any undesirable compounds or plant parts. The samples were shade dried for about 15 days to avoid any possible photochemical degradation of bioactive compounds present in them. Then they were coarsely powdered and stored in air tight bottles for further work.

Hot extraction by Sohxlet's apparatus and cold extraction by Maceration process were carried out using various organic solvents starting with Petroleum ether, Diethyl-ether, acetone, ethyl acetate, Iso-propanol, methanol and ethanol:Water (3:1) with increasing polarity. For hot extraction, each solvent $200 \mathrm{ml}$ was taken along with the $50 \mathrm{~g}$ of powdered bark of Rhizophora mucronata for a period of 8 hours. For cold extraction, a known weight
(200 g) of the extract was taken in the container and 500 $\mathrm{ml}$ of above solvents were added starting from petroleum ether, till ethanol: water (3:1) was added one after the other, each solvent was used for 2 weeks, the containers were sealed with occasional stirring and shaking. After 2 weeks, the mixture was filtered through Whatmann filter paper 1 . The filtered thus obtained was evaporated in room temperature to obtain the crude extract, which is stored at $4^{\circ} \mathrm{C}$ for further use.

\subsection{Cytotoxicity screening using MTT Assay}

The Liver cancer cell line $\left(\mathrm{HepG}_{2}\right)$ were plated separately using 96 well plates with the concentration of $1 \times 10^{4}$ cells/ well in DMEM media with $1 \mathrm{X}$ Antibiotic Antimycotic Solution and $10 \%$ foetal bovine serum (Hi media, India) in $\mathrm{CO}_{2}$ incubator at $37^{\circ} \mathrm{C}$ with $5 \% \mathrm{CO}_{2}$. The cells were then exposed to toxicant medium containing $2 \% \mathrm{CCl}_{4}$, Ethanol $60 \%$ and paracetamol $14 \mathrm{mM}$. The cells were then washed with $200 \mu \mathrm{L}$ of $1 \mathrm{X}$ PBS, then the cells were treated with various test concentration $(18.85,37.5,75,150$ and $300 \mu \mathrm{g} /$ $\mathrm{ml}$ ) of compound in serum free media and incubated for $24 \mathrm{~h}$. The medium was aspirated from cells at the end of the treatment period. $0.5 \mathrm{mg} / \mathrm{mL}$ MTT prepared in $1 \mathrm{X}$ PBS was added and incubated at $37^{\circ} \mathrm{C}$ for $4 \mathrm{~h}$ using $\mathrm{CO}_{2}$ incubator. After incubation period, the medium containing MTT was discarded from the cells and washed using 200 $\mu \mathrm{L}$ of PBS. The formed crystals were dissolved with 100 $\mu \mathrm{L}$ of DMSO and thoroughly mixed. The development of color intensity was evaluated at $570 \mathrm{~nm}$. The formazan dye turns to purple blue color. The absorbance was measured at $570 \mathrm{~nm}$ using micro plate reader. Silymarin was used as the positive control.

\section{Results}

\section{1. $\mathrm{CCl}_{4}$ induced toxicity}

$\mathrm{CCl}_{4}$ exposed $\mathrm{HepG}_{2}$ cells showed the percentage viability of $31.03 \%$ at the concentration of $2.0 \%$ of $\mathrm{CCl}_{4}$. These exposed cells when treated with different concentration $(18.85,37.5,75,150$ and $300 \mu \mathrm{g} / \mathrm{ml})$ of the bark extract of Rhizophora mucronata (BERM) showed a dose dependent increase in the percentage of viable cells. The percentage viability ranged between 49.3 to $99.3 \%$ at 18.85 to 300 $\mu \mathrm{g} / \mathrm{ml}$ (Table 1 ). The increase in percentage of viable cells at the concentration of $300 \mu \mathrm{g} / \mathrm{ml}$ for the extract has $99.3 \%$ whereas for the Silymarin at the same concentration \% of viable cells found out to be $92.61 \%$ (Fig. 1) and (Fig. 2) respectively. The IC50 value of the treated $\mathrm{HepG}_{2}$ cells for the sample was noted to be $21.53 \mu \mathrm{g} / \mathrm{ml}$. Figure-3 depicts the light microscopic images of the Standard and the sample at different concentrations. Thus, from the results it can be concluded that the extract has the same potential bioactivity as compared to the standard Silymarin. 


\begin{tabular}{|c|c|c|}
\hline Tested concentra- & \multicolumn{2}{|c|}{$\mathrm{CCl}_{4}$ intoxicated } \\
\hline & $\begin{array}{l}\text { Standard (Si- } \\
\text { lymarin) \% of } \\
\text { Viable cells }\end{array}$ & $\begin{array}{c}\text { BERM Extract \% } \\
\text { of Viable cells }\end{array}$ \\
\hline 18.85 & $59.81 \pm 2.98$ & $49.36 \pm 1.13$ \\
\hline 37.5 & $77.00 \pm 2.84$ & $65.50 \pm 1.03$ \\
\hline 75 & $83.12 \pm 1.47$ & $73.94 \pm 4.65$ \\
\hline 150 & $86.81 \pm 0.8$ & $84.28 \pm 4.40$ \\
\hline 300 & $92.61 \pm 1.42$ & $99.36 \pm 4.01$ \\
\hline
\end{tabular}

Table 1 Illustrates the cyto toxicity (MTT ASSAY) results carried out on the crude bark extract of Rhizophora mucronata and the control intoxicated with $\mathrm{CCl}_{4}$, showing \% of viable cells both in extract and standard Silymarin. The results were conducted in triplicates $(n=3)$, Mean \pm Standard deviation.

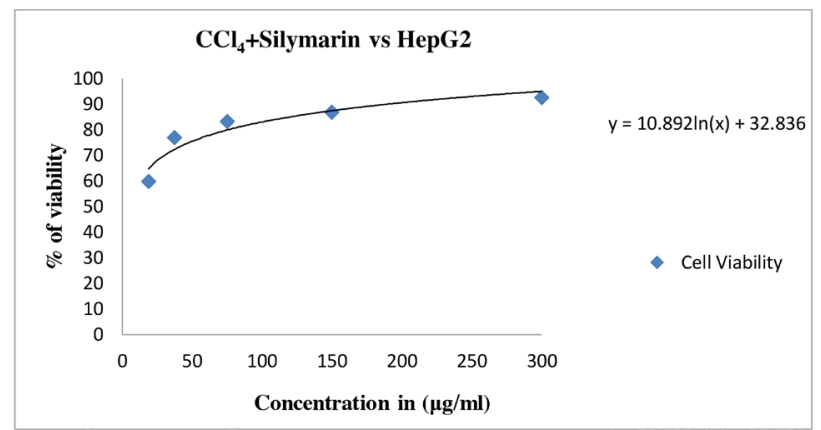

Figure 1 Shows the graph for Standard Silymarin intoxicated with $\mathrm{CCl}_{4}$, the \% percentage of viable cells at different concentrations of standard.

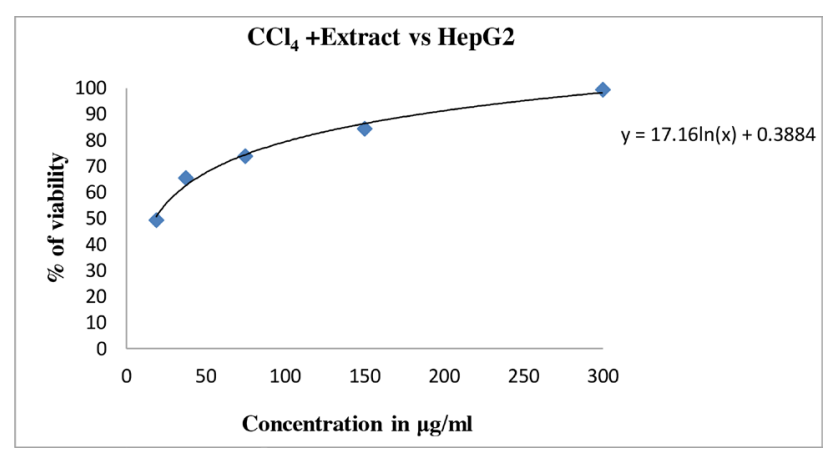

Figure 2 Shows the graph for BERM extract intoxicated with $\mathrm{CCl}_{4}$, the $\%$ percentage of viable cells at different concentrations of extract.

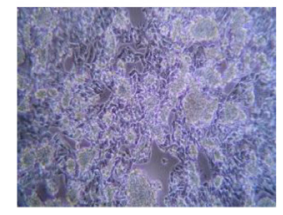

$18.85 \mu \mathrm{g} / \mathrm{ml}$

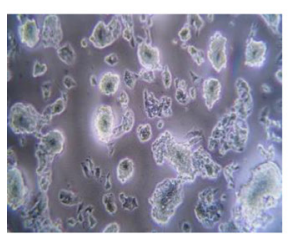

$18.85 \mu \mathrm{g} / \mathrm{ml}$

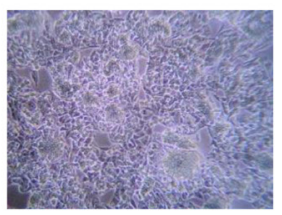

$37.5 \mu \mathrm{g} / \mathrm{ml}$

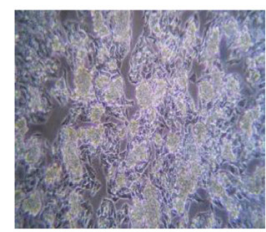

$37.5 \mu \mathrm{g} / \mathrm{ml}$

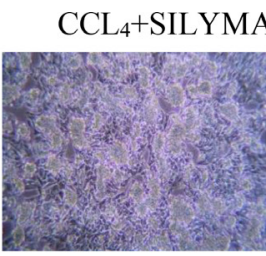

$75 \mu \mathrm{g} / \mathrm{ml}$ $\mathrm{CCL}_{4}+\mathrm{EXTRACT}$

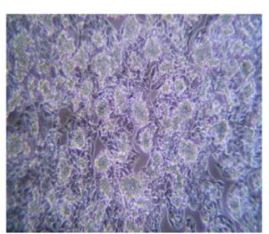

$75 \mu \mathrm{g} / \mathrm{ml}$

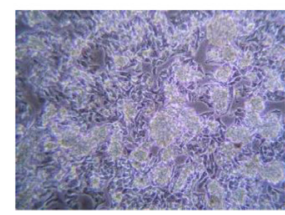

$150 \mu \mathrm{g} / \mathrm{ml}$

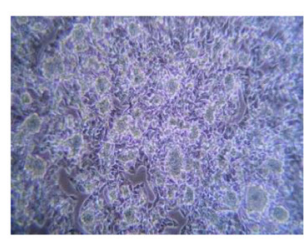

$150 \mu \mathrm{g} / \mathrm{ml}$

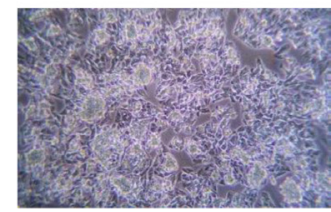

$300 \mu \mathrm{g} / \mathrm{ml}$

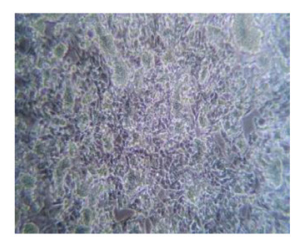

$300 \mu \mathrm{g} / \mathrm{ml}$

Figure 3 Light microscopic images of Standard Silymarin and the sample BERM at different concentrations when induced with $\mathrm{CCl}_{4}$ on $\mathrm{HepG}_{2}$ cell lines 


\subsection{Ethanol Induced toxicity}

Ethanol induced toxicity to $\mathrm{HepG}_{2}$ Cells showed the percentage viability of $23.17 \%$ at the concentration of $60 \%$ of Ethanol. These ethanol exposed cells when treated with the different concentrations as stated above of the extract showed a dose dependent increase in the $\%$ of viable cells. The percentage viability for the extract was ranged from $52.3 \%$ to $97.67 \%$ from lower to higher concentration of extract (Table 2). The IC50 values for the extract and the standard silymarin was found to be $12.61 \mu \mathrm{g} / \mathrm{ml}$ and $<18.85 \mu \mathrm{g} / \mathrm{ml}$ (Fig. 4) and (Fig. 5) respectively. Fig. 6 depicts the light microscopic images of the Standard Silymarin and the sample at different concentrations. The $\%$ of viable cells of the extract was almost similar to as obtained for the standard Silymarin.

\begin{tabular}{|c|c|c|}
\hline $\begin{array}{c}\text { Tested concentra- } \\
\text { tion }(\mu \mathrm{g} / \mathrm{ml})\end{array}$ & \multicolumn{2}{|c|}{ Ethanol intoxicated } \\
\hline & $\begin{array}{c}\text { Standard (Si- } \\
\text { lymarin) \% of } \\
\text { Viable cells }\end{array}$ & $\begin{array}{c}\text { BERM Extract \% } \\
\text { of Viable cells }\end{array}$ \\
\hline 18.85 & $74.47 \pm 1.90$ & $52.37 \pm 4.14$ \\
\hline 37.5 & $77.95 \pm 0.60$ & $70.99 \pm 2.10$ \\
\hline 75 & $84.91 \pm 1.04$ & $79.95 \pm 4.86$ \\
\hline 150 & $89.02 \pm 1.19$ & $88.71 \pm 3.25$ \\
\hline 300 & $95.36 \pm 3.25$ & $97.67 \pm 2.45$ \\
\hline
\end{tabular}

Table 2 Illustrates the cyto toxicity (MTT ASSAY) results carried out on the crude bark extract of Rhizophora mucronata and control intoxicated with Ethanol, showing \% of viable cells both in extract and standard Silymarin. The results were conducted in triplicates $(\mathrm{n}=3)$, Mean \pm Standard deviation.

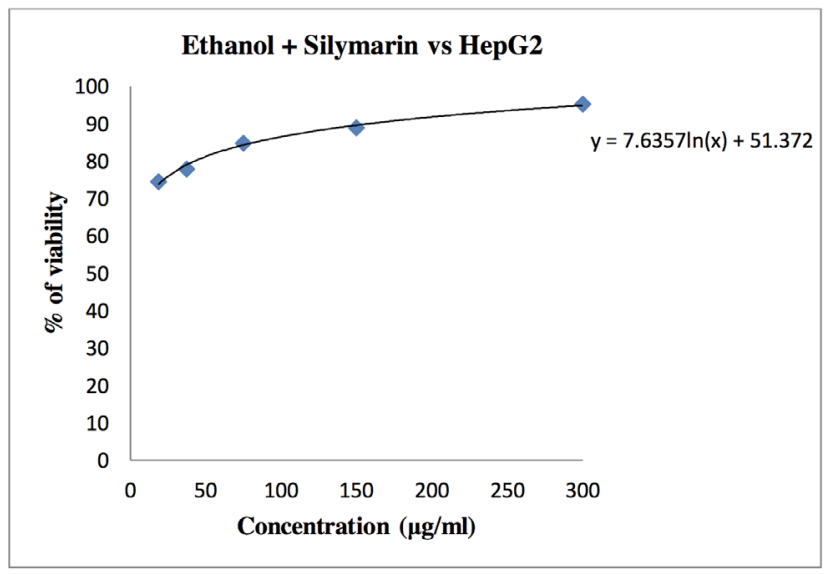

Figure 4 Graph for Standard Silymarin intoxicated with Ethanol, the $\%$ percentage of viable cells at different concentrations of standard.

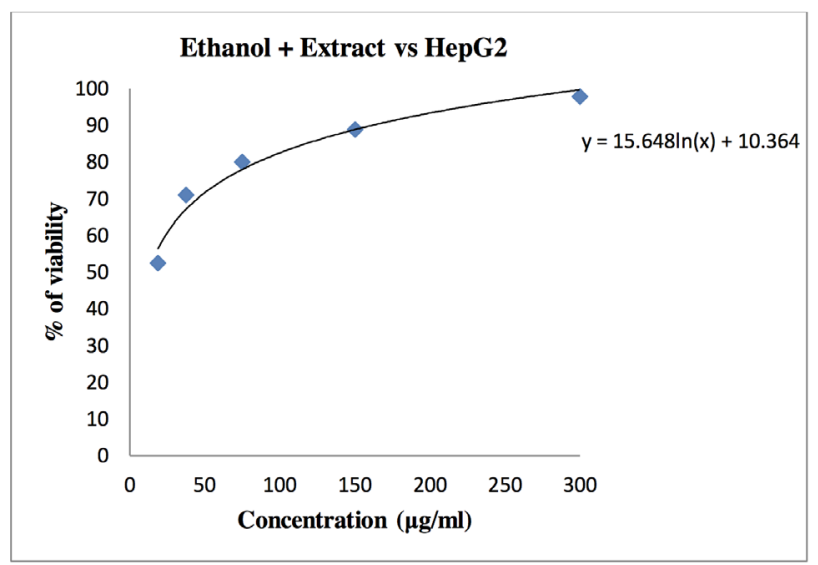

Figure 5 Shows the graph for BERM extract intoxicated with Ethanol, the \% percentage of viable cells at different concentrations of extract.

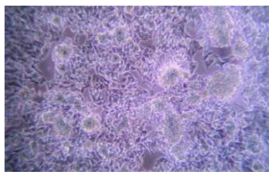

$18.85 \mu \mathrm{g} / \mathrm{ml}$

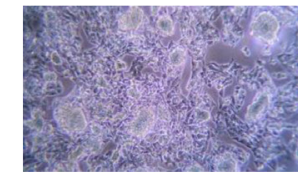

$37.5 \mu \mathrm{g} / \mathrm{ml}$
ETHANOL+ SILYMARIN

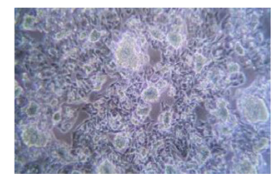

$75 \mu \mathrm{g} / \mathrm{ml}$

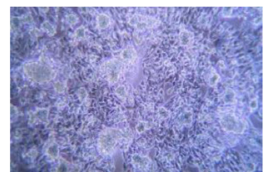

$150 \mu \mathrm{g} / \mathrm{ml}$

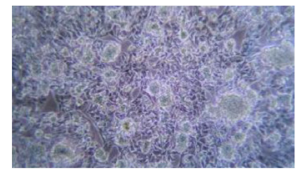

$300 \mu \mathrm{g} / \mathrm{ml}$

\section{ETHANOL+EXTRACT}

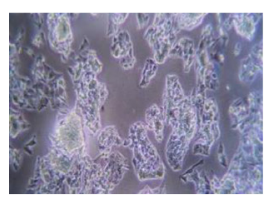

$18.85 \mu \mathrm{g} / \mathrm{ml}$

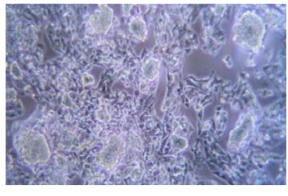

$37.5 \mu \mathrm{g} / \mathrm{ml}$

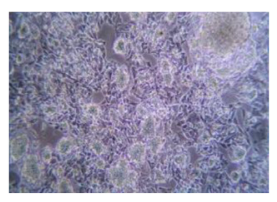

$75 \mu \mathrm{g} / \mathrm{ml}$

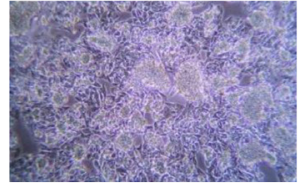

$150 \mu \mathrm{g} / \mathrm{ml}$

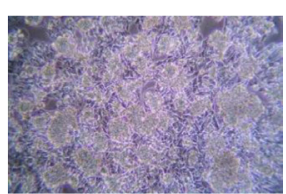

$300 \mu \mathrm{g} / \mathrm{ml}$

Figure 6 Light microscopic images of Standard Silymarin and the sample BERM at different concentrations when induced with Ethanol on $\mathrm{HepG}_{2}$ cell lines 


\subsection{Paracetamol Induced Toxicity}

Paracetamol exposed $\mathrm{HepG}_{2}$ cells when subjected to a series of known concentrations of extract, there is a dose dependent increase in the \% of viable cells were found (Table 3). At $300 \mu \mathrm{g} / \mathrm{ml}$ concentration, the percentage of viable cells for the extract was found to be $75.37 \%$ and that for standard to be $78.37 \%$ (Fig. 7) and (Fig. 8). The IC50 values for both extract and standard Silymarin was found to be $21.42 \mu \mathrm{g} / \mathrm{ml}$ and $9.07 \mu \mathrm{g} / \mathrm{ml}$ respectively. Fig. 9 depicts the light microscopic images of the Standard and the sample at different concentrations. (Table 4) (Fig. 10) shows an overlay graph of the IC50 values of all the three models both for extract and standard Silymarin.

\begin{tabular}{|c|c|c|}
\hline $\begin{array}{c}\text { Tested concentra- } \\
\text { tion }(\mu \mathrm{g} / \mathrm{ml})\end{array}$ & \multicolumn{2}{|c|}{ Paracetamol intoxicated } \\
\hline & $\begin{array}{c}\text { Standard (Si- } \\
\text { lymarin) \% of } \\
\text { Viable cells }\end{array}$ & $\begin{array}{c}\text { BERM Extract \% } \\
\text { of Viable cells }\end{array}$ \\
\hline 18.85 & $55.27 \pm 2.58$ & $49.47 \pm 0.98$ \\
\hline 37.5 & $61.39 \pm 0.93$ & $59.91 \pm 2.24$ \\
\hline 75 & $69.51 \pm 0.15$ & $64.76 \pm 2.39$ \\
\hline 150 & $71.31 \pm 0.98$ & $69.30 \pm 4.25$ \\
\hline 300 & $78.37 \pm 4.28$ & $75.37 \pm 5.81$ \\
\hline
\end{tabular}

Table 3 Illustrates the cyto toxicity (MTT ASSAY) results carried out on the crude bark extract of Rhizophora mucronata and control intoxicated with paracetamol, showing \% of viable cells both in extract and standard Silymarin. The results were conducted in triplicates $(\mathrm{n}=3)$, Mean \pm Standard deviation.

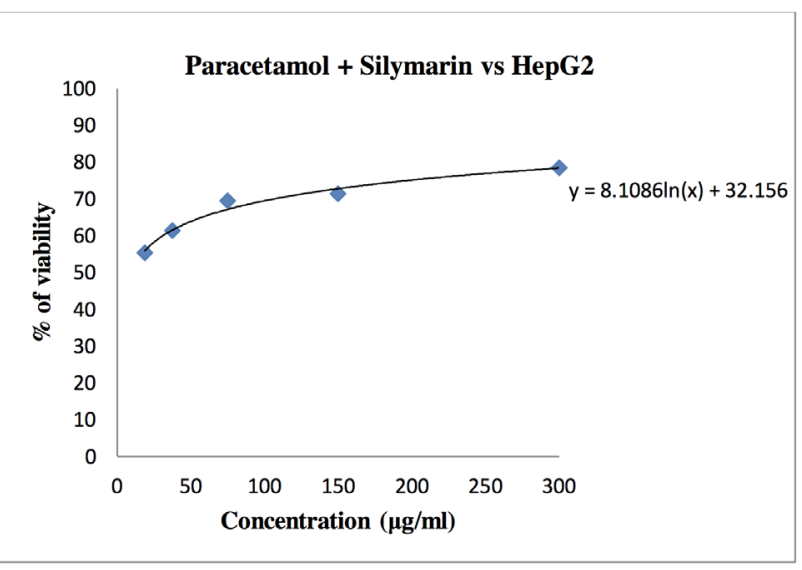

Figure 7 Shows the graph for Standard Silymarin intoxicated with Paracetamol, the \% percentage of viable cells at different concentrations of standard.

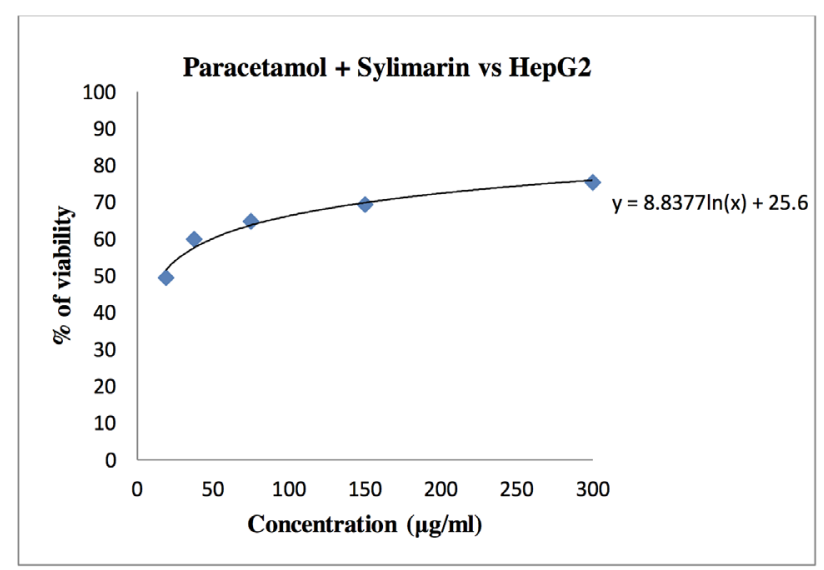

Figure 8 Shows the graph for BERM extract intoxicated with Paracetamol, the \% percentage of viable cells at different concentrations of extract.

PARACETAMOL+SILYMARIN

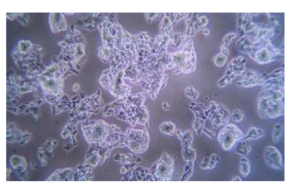

$18.85 \mu \mathrm{g} / \mathrm{ml}$

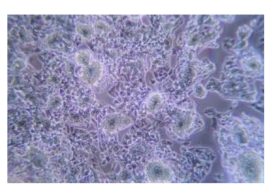

$37.5 \mu \mathrm{g} / \mathrm{ml}$

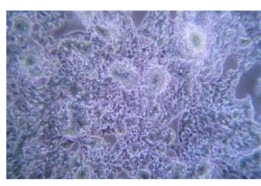

$75 \mu \mathrm{g} / \mathrm{ml}$

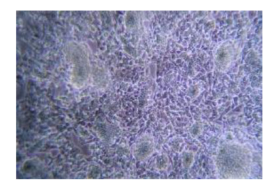

$150 \mu \mathrm{g} / \mathrm{ml}$

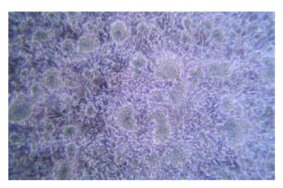

$300 \mu \mathrm{g} / \mathrm{ml}$

PARACETAMOL+EXTRACT

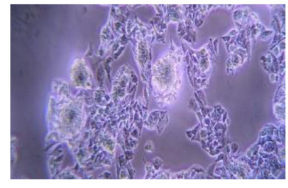

$18.85 \mu \mathrm{g} / \mathrm{ml}$

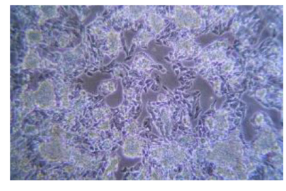

$37.5 \mu \mathrm{g} / \mathrm{ml}$

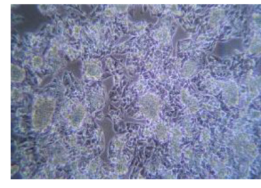

$75 \mu \mathrm{g} / \mathrm{ml}$

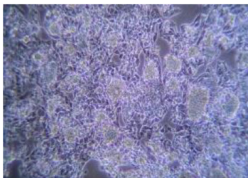

$150 \mu \mathrm{g} / \mathrm{ml}$

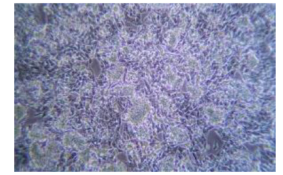

$300 \mu \mathrm{g} / \mathrm{ml}$

Figure 9 Light microscopic images of Standard Silymarin and the Sample BERM at different concentrations when induced with Paracetamol on $\mathrm{HepG}_{2}$ cell lines. 


\begin{tabular}{|c|c|c|}
\hline Model & $\begin{array}{l}\text { Sample and } \\
\text { Standard }\end{array}$ & $\begin{array}{l}\text { IC50 values } \\
(\mu \mathrm{g} / \mathrm{ml})\end{array}$ \\
\hline \multirow{2}{*}{$\mathrm{CCl}_{4}$ model } & $\mathrm{CCL}_{4}+$ Silymarin & $4.806(<18.85 \mu \mathrm{g} / \mathrm{ml})$ \\
\hline & $\mathrm{CCL}_{4}+$ Extract & 21.53 \\
\hline \multirow{2}{*}{ Ethanol model } & $\begin{array}{c}\text { Ethanol + Sily- } \\
\text { marin }\end{array}$ & $1.19(<18.85 \mu \mathrm{g} / \mathrm{ml})$ \\
\hline & Ethanol + Extract & 12.61 \\
\hline \multirow{2}{*}{$\begin{array}{l}\text { Paracetamol } \\
\text { model }\end{array}$} & $\begin{array}{c}\text { Paracetamol + } \\
\text { Silymarin }\end{array}$ & $9.07(<18.85 \mu \mathrm{g} / \mathrm{ml})$ \\
\hline & $\begin{array}{c}\text { Paracetamol + } \\
\text { Extract }\end{array}$ & 21.42 \\
\hline
\end{tabular}

Table 4 Illustrates the overlay data of three models $\left(\mathrm{CCl}_{4}\right.$, Ethanol and Paracetamol intoxicated) on $\mathrm{HepG}_{2}$ cell lines, IC50 values $(\mu \mathrm{g} / \mathrm{ml})$ for standard and extract respectively.

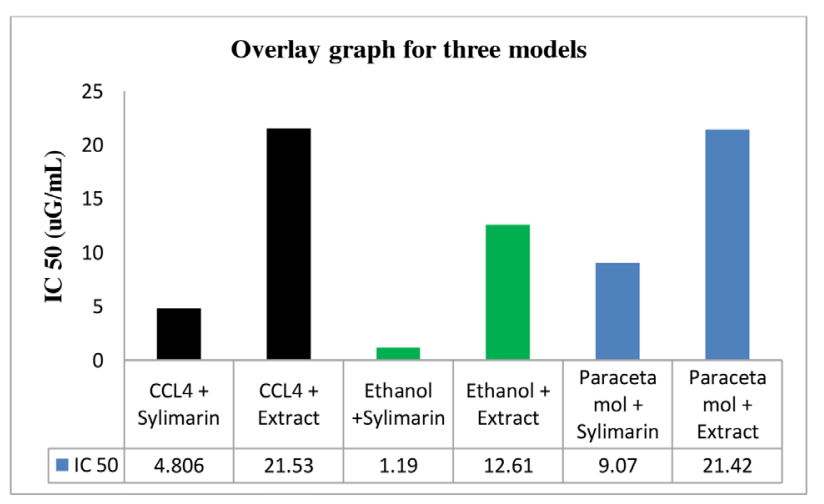

Figure 10 Illustrates the overlay data of IC50 values for all the three models for the extract and standard Silymarin respectively.

\section{Discussion}

The most commonly used model for screening of anti hepato toxic or hepatoprotective activity of drugs are $\mathrm{CCl}_{4}$ induced toxicity in cell lines $[9,10]$. The xenobiotic hepatotoxicity is characterized by liver injuries caused due to $\mathrm{CCl}_{4}$. Since, viral acute hepatitis is similar to that of $\mathrm{CCl}_{4}$ induced damage to liver [11], in this study $\mathrm{CCl}_{4}$ toxicity has been chosen as one of the model. It is well established that $\mathrm{CCl}_{4}$ gets accumulated at parenchymal and other cells in liver, and gets activated by cytochrome- 450 monooxygenase to form an unstable compound called trichloromethyl radical $\left(\mathrm{CCl}_{3}\right)$. This $\mathrm{CCl}_{3}$ molecule produces lipid peroxides by alkylating the cellular proteins, PUFA and other macromolecules in the presence of oxygen leading to the damage of liver cells [12]. In the present study, the extract is capable of neutralize the $\mathrm{CCl}_{4}$ toxicity as per the results obtained. The maximum concentration at $300 \mu \mathrm{g} /$ $\mathrm{ml}$, the viable cells found to be approximately $90 \%$ which indicates that the extract has the potency to regenerate the $\mathrm{CCl}_{4}$ toxicated cells. Similar results were obtained in the study by [13] wherein the total alkaloid fraction of $H y$ grophila auriculata at the concentration of $80 \mu \mathrm{g} / \mathrm{ml} \mathrm{ob-}$ tained $92 \%$ of viable cells intoxicated with $\mathrm{CCl}_{4}$.

In another study, during the evaluation of hepatoprotective and antioxidant potential of methanolic extract of Polyalthiya longifolia fruits, intoxicated with $\mathrm{CCl}_{4}$, the fruit extract at $500 \mu \mathrm{g} / \mathrm{mL}$, able to retrieve $84.5 \%$ of viable cells [14].

In worldwide, paracetamol is used either as antipyretic or analgesic drugs since $19^{\text {th }}$ century. It is similar to non-steroidal anti-inflammatory drugs (NSAIDs) in its mechanism of action. However, it is considered safe when it has been taken within the therapeutic dosage limits. Paracetamol overdose may give rise to a wide range of disorders in almost different vital organs viz, liver, kidneys, adrenals, brain, etc. The hepatotoxic effects of Paracetamol are attributed to yield toxic trichloroethylene radicals that can act as free radical initiators. These free radicals react with complex macromolecules within the tissues and aids lipid per oxidation which further leads to the damage and chronic injury to the cells. The symptoms which include nausea with or without vomiting, malaise and abdominal pains due to paracetamol overdose may often mistake for viral prodrome.

In a similar study, wherein in-vitro hepatoprotective activity of Albizia lebbeck, Cassia occidentalis and Swertia chirata on $\mathrm{HepG}_{2}$ cells [15] on comparing with the reference standard where Silymarin showed $156.3 \pm 1.69 \%$ cell viability in seed extracts of A. lebbeck, $154 \pm 1.63 \%$ cell viability in seed extracts of $C$. occidentalis and 156.6 $\pm 2.49 \%$ cell viability in leaves extract of $S$. chirata against Paracetamol induced hepatotoxicity on $\mathrm{HepG}_{2}$ cell lines. Studies have promisingly shown hepato protection and immune modulation by methanolic and ethanolic extract of A. lebbeck and S. chirata [16-18]. Promising results have also been shown in the model of Wistar rats proving histologically the beneficial effect of the ethanolic extract of $A$. lebbeck in hepato protection [19]. Our study also showed the hepato protection of the bark extract (3:1) of Rhizophora mucronata against Paracetamol induced intoxication.

Alcoholism, intake of alcohol may one of the major causes of hepatic injury or liver damage. Although the mechanism of alcohol induced hepatotoxicity is very complex and in depth knowledge of different pathways required to understand for its toxicity. However oxidative stress and lipid per oxidation may be attributed to its toxicological nature. Due to excessive alcohol consumption one can inherit alcoholic disorder which in turn leads to chronic liver disorders. Excessive alcohol consumption leads to alcohol hepatitis, then fibrosis, liver cirrhosis, then ultimately hepatic liver failure (HLF). In the present study, ethanol induced hepatotoxicity on $\mathrm{HepG}_{2}$ cells when treated with the extract neutralized by the extract at the concentration of $300 \mu \mathrm{g} / \mathrm{mL}$, able to retrieve more than $75 \%$ of cells. This is the indication that the extract is capable of regenerating the damaged cells caused due to the toxicant ethanol.

Thus, our study document the potential influence of the bark extract of Rhizophora mucronata extract against $\mathrm{HepG}_{2}$ cell lines using MTT assay. The intensity of $\mathrm{HepG}_{2}$ cell density was increased while increasing the concentration of Rhizophora mucronata extract from $18.85 \mu \mathrm{g} /$ 
$\mathrm{ml}$ to $300 \mu \mathrm{g} / \mathrm{ml}$ when treated with different toxicants viz, $\mathrm{CCl}_{4}$, ethanol and paracetamol. This infers the existence of dose dependent properties of Rhizophora mucronata extract against different toxicants on cell lines which was found effective. Study reveals that the ethanol: water (3:1) fraction of Rhizophora mucronata evidence the existence of cytotoxic effect and also document the evidence of bioactive compounds which profound to be the influencing factor for the anti-hepato toxic effect. Thus, from the study it can be concluded that the extract of Rhizophora mucronata contains potent bioactives capable of inducing the hepatoprotective activity.

\section{Conclusion}

The Several studies have been carried on Rhizophora mucronata and its parts for its therapeutic effects, however very little has been documented. The results obtained from the current study, clearly suggested that the bark extract of Rhizophora mucronata at different concentrations capable of neutralizing a wide range of toxicants viz, $\mathrm{CCl}_{4}$, paracetamol and alcohol overdose. Further, the study also proved that the extract contained potent bioactives with high clinical value which reverted the toxic cells to the normal ones. The study can be further taken to next level, the extract can be tested in animals to support or confirm the findings in our present study. The extract can be used as an alternate source of hepatoprotectant w.r.t the conventional liver savers.

\section{Acknowledgement}

All the authors are grateful to the management and the laboratory facilities provided by Mohamed Sathak College of Arts and Science, Shollinganallur for the successful completion of the study.

\section{References}

1. Dienstag JL, Isselbacher KJ. Toxic and drug-induced hepatitis, 15th edn. Chapter 296, In: Ha rrison's Principles of Internal Medicine. Braunwald E, et al, The McGraw-Hill Companies, In. 2001;2:737=1742.

2. Ward FM, Daly MJ. Hepatic Disease, In: Clinical Pharmacy and Therapeutics. Churchill Livingstone press, New York. 1999;195-212.

3. LawK,BruntEM. Non alcoholic fatty liver disease. Clinics. Liver. Dis. 2010;14:591-604.

4. Stickel F, Schuppan D. Herbal medicine in the treatment of liver diseases. Digestive Liver Dis. 2007;39:293304.

5. Recknagel RO, Glende EA, Dolak JA, Waller RL. Mechanism of carbon tetrahloride hepatotoxcity. 1989;33:139154.

6. Kallappa SG, Jambilingappa LK. Evaluation of hepatoprotective activity of aqueous extract of Azadirachta indica (neem) leaves against paracetamol induced hepatotoxicity in albinorats. Pharmacologyonline. 2011;2: 96-108.

7. Recknagel RO. A new direction in the study of carbon tetrahloride hepatotoxcity. 1983;33:401-408.

8. Wang XD. Chronic alcohol intake interferce with retinoid metabolism and Signaling. Nutr Rev. 1999;57:5159.PUB MED-S0741832905001011.

9. Lin SC, Lin CH, Lin CC, Chen CF, Chen IC, et al. Hepatoprotective effect of Arctium lappolinne on liver injuries induced by chronic ethanol consumtion and potentiated by carbon tetrachloride. J Biomed Sci. 2002;9:401409.

10. Clawson GA. Mechanism of carbon tetrachloride hepatotoxicity. Pathol Immunopathol Res. 1989;8:104-112.

11. Rubinstein D. Epinephrine release and liver glycogen levels after carbon tetrachloride administration. Amj Physiol. 1962;203:1033-7.

12. Bishayee A, Sarkar A, Chaterjee M. Hepatoprotective activity of carrot (Daucus carota) against carbon tetrachloride intoxication in mouse liver. J Ethnopharmacol. 1995;47:69-74.

13. Raj VP, Chandrasekhar RH, Vijayan P, Dhanaraj SA, Rao $\mathrm{MC}$, Rao VJ, et al. In vitro and in vivo hepatoprotective activity of the total alkaloid fraction of Hygrophila auriculata leaves. 2010;42(2):99-104.

14. Jayaraman R, Christina M. Evaluation of Hepatoprotective and antioxidant potential of methanolic extract of Polyalthiya longifolia fruits: An In-vitro and In-vivo approach. Journal of Appli Pharma Sci. 2013;3(2):69-76.

15. Mukherjee S, Sur A, Maiti BR. Hepatoprotective effect of Swertia chirata on rat. Indian J Exp Biol. 1997;35(4):384-8.

16. Sivakrishnan S, Kottaimuthu A. Hepatoprotective activity of ethanolic extract of aerial parts of Albizia procera roxb (Benth.) Against paracetamol induced liver toxicity on Wistar rats. Int J Pharm Pharm Sci. 2014;6(1):233-8.

17. Mahmood S, Hussain S, Tabassum S, Malik F, Riaz H. Comparative phytochemical, hepatoprotective and antioxidant activities of various samples of Swertia chirayita collected from various cities of Pakistan. Pak J Pharm Sci. 2014;27(6):1975-83. 
18. Shirode D, Roy SP, Patel T, Rajendra SV, Jyothi TM, Baganal $\mathrm{P}$, et al. Evaluation of hepatoprotective effect of leaves of seventy percent ethanolic extract of Albizia lebbeck in paracetamol induced experimental hepatic damage. Plant Arch. 2008;8(2):797-801.

19. Anil K, Manju OP, Nishant R. In-vitro hepatoprotective activity of Albizia lebbeck, Cassia occidentalis and Swertia chirata on $\mathrm{HepG}_{2}$ cells. Asian J Pharm Clin Res. 2016;9(4):276-280. 